\title{
PECULIARITIES OF THE RUSSIAN BANKRUPTCY LAW ENFORCEMENT
}

\begin{abstract}
The authors consider some issues related to bankruptcy law enforcement, recovery of the entity's (bank) soundness and repayment ability, promotion of business activity, as well as the terms of challenging queer transactions consummated by the banks in bankruptcy proceedings. Based on the analysis of accumulated arbitration courts' practice the Authors reveal the peculiarities of challenging queer transactions in accordance with the existing bankruptcy legislation and explain the legal ideas of ensuring financial stabilization.
\end{abstract}

\section{Key words}

Banking law; bankruptcy legislation; financial stabilization

\section{Introduction}

Legal regulation of the institute of insolvency (bankruptcy) is one of the most actively developing spheres of legislation, as it reflects direct and backward linkages between economy and law. By their economic and legal nature bankruptcy processes are aimed at strengthening and increasing the efficiency of economy. The development of the given institute implies constant renewal of legal norms with the aim of decreasing economic risks by either liquidating or restructuring economically inefficient entities. From the viewpoint of legal support, the most crucial issues are those of protecting creditors' rights, ensuring financial and economic discipline, improving the reliability of credits and goods circulation and the quality of corporate management of entities.

The institute of insolvency in modern Russia (as there was no bankruptcy legislation in the USSR) developed in the form of three laws. The first one was the Law of the Russian
Federation dated 19.11.1992 № 3929-1 "On the Insolvency (Bankruptcy) of an Entity" [Law of the Russian Federation of 19 November 1992 № 3929], the second one was the Federal Law of 8.01.1998 № 6-FZ “On the Insolvency (Bankruptcy)” [Federal Law of 8.01.1998 № 6-Ф3].

In 2002 in his annual President's Message to the Federal Assembly of the Russian Federation V.V. Putin noted: "We must make the mechanism of bankruptcy proceedings and of the recovery of businesses more transparent, more market-oriented, and therefore less sensitive to corruption" [www. kremlin.ru/events/president/transcripts/21567 (accessed 5.11.2017)]. So to establish order in the area of bankruptcy a third legal act was adopted, the Federal Law of 26.10.2002 № 127-FZ “On the Insolvency (Bankruptcy)” [Federal Law of 26.10.2002 № 127-FZ] (hereafter, the Bankruptcy Law).

The model that was embodied in the Bankruptcy Law was most compromising. It softened the "suddenness of application of bankruptcy proceedings" for business, thus helping to get rid of the notorious practice of the 90s-2000s, when the given institute was often used as a means of redistribution of property or a method of political or economic pressure. The fundamental concepts of the law were also implemented in other branches of legislation (e.g. criminal law); more independence was given to the institute of insolvency representatives in terms of extending the rights of self-regulating organizations; the problem of the "absent debtor" was settled. However, the law was changed and amended and since 1.01.2017 it has been effective in the version of 3.07.2016.

One should also note here that in addition to the general legal acts mentioned above there were also special ones: the Federal Law of 25 February 1999 № 40-FZ “On the 
Insolvency (Bankruptcy) of Credit Organizations" [Federal Law of 25.02.1999 № 40-FZ], and the Federal Law of 24 June 1999 № 122-FZ “On the Peculiarities of Insolvency (Bankruptcy) of Subjects of Natural Monopolies of Fuel and Energy Sector” [Federal Law of 24 June 1999 № 122-FZ] that are of no effect at present.

There is a need for scientific understanding of the inadequacy of the development of infrastructure of bankruptcy legislation enforcement, originating from the comprehensive nature of legal regulation and selective application of civil and public law methods supported by court practice.

The given article highlights the peculiarities of regulation of the insolvency of credit organizations that act as a blood vessel of any economy. It is axiomatic that financial stability of a bank system predetermines the stability of economic development, as well as social peace and security.

\section{Main part}

In his annual Message to the Federal Assembly of 1 December 2016, V.V. Putin noted that "...the bank system is getting rid of the establishments that infringe the law and clients' rights, and consummate suspicious financial transactions. The bank sector has been sanitized... All of this is a good basis for rapid revitalization of economy and the development of lending to real economy" [www.kremlin.ru/events/ president/news/53379 (accessed 5.11.2017)]. It would be fair to draw attention to the positive vector of development of bankruptcy law enforcement and court practice here. The chairman of the Supreme Court of the Russian Federation V.M. Lebedev has pointed out positive developments in the arbitration practice: “... after the merger (of Higher courts) the efficiency of court's work has increased, the Supreme Court has become more productive in working out its legal positions and in the analysis of judicial practice [www.kommersant.ru/doc/2824328 (accessed 6.10.2017)]. Using the experience of the judicial norm setting and developing court practice of the Supreme Court of Arbitration in the work of Supreme Court of the Russian Federation contributes to legal certainty and legal support of economic relations.

Challenging queer transactions consummated by a bank is not a simple issue in the sphere of bankruptcy law enforcement.

The analysis of arbitration practice shows that insolvency representatives quite often challenge queer transactions consummated by the banks that are involved in bankruptcy proceedings on special grounds stipulated in the bankruptcy legislation [www.kad.arbitr.ru (accessed 5.10.2017)]. To our mind, the given legal option is directly related to additional protection of the creditors' rights, extra search for the sources of bankruptcy assets. At the same time it preventively contributes to strengthening financial discipline and economic order.

It is important that the special grounds for challenging queer transactions consummated by banks are stipulated in a separate norm, Article 61.2 chapter III.I of the Federal Law of 26.10.2002 № 127-FZ “On the Insolvency (Bankruptcy)" [Federal Law of 26.10.2002 № 127-FZ], according to which a queer transaction can be challenged by virtue of two special grounds:

- unequal reciprocal fulfilment of obligations by the other party of the transaction (point 1 Article 61.2 of the Bankruptcy Law);

- a transaction with the intention to inflict harm to the property rights of the bank's creditors (point 2 Article 61.2 of the Bankruptcy Law).

The ground stipulated in point 1 Article 61.2 of the Bankruptcy Law must be proved by the insolvency representative of the debtor. As it follows from the explanation in point 8 of the Resolution of the Plenum of the Supreme Court of Arbitration of the Russian Federation of 23.12.2010 № 63 (as amended of 30.07.2013) "On Some Issues Related to the Application of Chapter III.I of the Federal Law 'On the Insolvency (Bankruptcy)' [Bulletin 2011] (hereafter, Resolution № 63), unequal reciprocal fulfilment of obligations by the other party of the transaction takes place if the price and (or) other terms of the transaction at the moment of its consummation are considerably worse for the debtor compared to the price and (or) other terms of similar transactions consummated under comparable circumstances. It is important to keep in mind that when comparing the terms of the challenged transaction with similar transactions one should consider both the terms of the transactions consummated by the bank and the terms of transactions consummated by other economic agents.

The analysis of arbitration practice reveals that courts accept a petition from a bank's insolvency representative invalidating a transaction only in case there is direct evidence of unequal reciprocal performance of obligations [www.kad.arbitr.ru (accessed 15.12.2017)].

If the insolvency representative does not provide appropriate evidence confirming that the value of property transferred by the bank as part of the challenged transaction is considerably higher than the value of counter-performance of obligations, courts deny the application to invalidate the queer transaction based on point 1 Article 61.2 of the Bankruptcy Law [www.kad.arbitr.ru (accessed 12.11.2017)].

It is also important to take into account the timeframe allowing for a queer transaction to be challenged. 
To invalidate a transaction based by virtue of point 1 Article 61.2 of the Bankruptcy Law it is necessary to prove that the queer transaction was consummated within one year before bankruptcy petition was accepted or after the petition was accepted.

Thus, the petition from the insolvency representative to invalidate a queer transaction is to be accepted if the applicant has proved and the court has found the following facts:

- inadequacy of counter-performance of obligations;

- consummating a transaction within a year before the bankruptcy petition was accepted.

There are also issues related to challenging the transactions consummated with the aim to inflict harm to the creditors' rights (point 2 Article 61.2 of the Bankruptcy Law).

First of all, one should take into account the explanations from point 5 of the Resolution of the Plenum of the Supreme Court of Arbitration of the Russian Federation of 23.12.2010 № 63, according to which to invalidate a transaction by virtue of point 2 Article 61.2 of the Bankruptcy Law, one has to prove the totality of the following circumstances:

- the transaction was consummated by the bank with the aim of inflicting property rights of the bank's creditors;

- as a result of the transaction consummation the property rights of the bank creditors have been inflicted;

- the other party of the transaction was aware or was supposed to be aware of the indicated aim of the debtor by the time of the transaction consummation.

In the case at least one of the given circumstances is not proved courts refuse to invalidate a transaction on the given grounds [www.kad.arbitr.ru (accessed 14.10.2017)].

It is important to keep in mind that when challenging a transaction based on point 2 Article 61.2 of the Bankruptcy Law the aim of inflicting harm to the banks' creditors' rights is assumed if two of the following circumstances are present at the same time:

- the bank was qualified for insolvency at the time of the transaction consummation;

- there is at least one of other circumstances present of those stipulated in paragraphs 2-5 of point 2 Article 61.2 of the Bankruptcy Law [Federal Law of 26.10.2002 № 127-FZ].

When defining the category of "harm to the creditors' property rights" one understands the following: the factual circumstances of decreasing the value and volume of the bank's property and (or) increasing the recovery claims to it, as well as other consequences of the transaction consummation or other legally meaningful actions that led or may lead to the full or partial loss of the opportunity for the creditors to satisfy their claims on account of the bank's property.

By virtue of point 1 Article 61.2 of the Bankruptcy Law it is assumed that the other party was aware of the aim to inflict harm to the creditors' property rights if it is qualified as an interested person (Article 19 of the Law), or if it was aware or was supposed to be aware of the infringement of the creditors' interests, or of the signs of insolvency of the debtor.

When the arbitration court settles the issue whether the other party of the transaction was supposed to be aware of the circumstances mentioned above, one considers whether it could establish the availability of the given circumstances by acting reasonably and with due circumspection.

As if follows from the explanations in point 7 of the Resolution of the Plenum of the Supreme Court of Arbitration of the Russian Federation of 23.12.2010 № 63, in the case of challenging a transaction on grounds of point 2 Article 61.2 of the Bankruptcy Law regarding the transactions that were consummated after the information about the implementation of a bankruptcy procedure had been published, one should proceed on the following basis: unless there is evidence to the contrary, any person should have learnt that a certain bankruptcy procedure had been implemented and therefore that there are signs of the debtor's insolvency.

If the queer transaction was consummated within a year before the debtor was declared bankrupt or after it, then the circumstances indicated in point 1 Article 61.2 of the Bankruptcy Law are sufficient for invalidating it and there is no need for the availability of other circumstances determined in point 2 of the given Article.

If the queer transaction with unequal reciprocal performance of obligations was consummated no later than within three years and no earlier than one year before the arbitration court accepted the bankruptcy petition, it can be invalidated only by virtue of point 2 Article 61.2 of the Bankruptcy Law and in the presence of the circumstances stipulated in this point.

The analysis of the arbitration practice shows that when challenging queer transactions consummated by banks by virtue of point 2 Article 61.2 of the Bankruptcy Law, arbitration courts rely on the recommendations stipulated in the given point [www.kad.arbitr.ru (accessed 8.09.2017)].

\section{Conclusion}

The positions mentioned above allow the Authors to make the following conclusions: 
- the development of the Russian insolvency (bankruptcy) legislation proves adequate legal reaction to economic challenges;

- general bankruptcy legislation contains special norms regulating bankruptcy procedures in the socially important sectors of economy, particularly the bank sector;

- there are certain peculiarities of regulating bankruptcy procedures in the bank sector, based on a combination of civil and public legal methods;

- the analysis of the arbitration court practice in the sphere of challenging queer transactions by the insolvency representatives proves the presence of public legal aspects in their activity, aimed at decreasing creditors' risks and removing inefficient credit organizations from the market of bank services.

\section{Bibliography}

Bulletin of Supreme Arbitration Court of the Russian Federation 2011, № 3.

Federal Law of 24 June 1999 № 122-FZ “On the Peculiarities of Insolvency (Bankruptcy) of Subjects of Natural Monopolies of Fuel and Energy Sector" [online], access from SPS KonsultantPlus.

Federal Law of 25.02.1999 № 40-FZ "On the Insolvency (Bankruptcy) of Credit Organizations" [online], access from SPS KonsultantPlus.

Federal Law of 26.10.2002 № 127-FZ (as amended on 03.07.2016) "On the Insolvency (Bankruptcy)" (as amended and effective from 1.01.2017) [online], access from SPS KonsultantPlus.

Federal Law of 8.01.1998 № 6-Ф3 “On the Insolvency (Bankruptcy)" [online], access from SPS KonsultantPlus.

International legal forum of the countries of Asia-Pacific region (Vladivostok, 2015) [online], www.kommersant.ru/ doc/2824328 (accessed 6.10.2017).

Law of the Russian Federation of 19 November 1992 № 3929-

1 "On the Insolvency (Bankruptcy) of Entities" [online], access from SPS KonsultantPlus.

President's Message to the Federal Assembly of the Russian Federation of 18.04.2002 [online], www.kremlin.ru/ events/president/transcripts/21567 (accessed 5.11.2017).

President's Message to the Federal Assembly of the Russian Federation of 1.12. 2016 [online], www.kremlin.ru/events/ president/news/53379 (accessed 5.11.2017).

Ruling of the Arbitration Court of Moscow circuit of 07.03.2014 № $\Phi 05-12800 / 2012$ on case № A40-59768/12; ruling of the Ninth Arbitration Court of Appeal of 23.12.2013 on case № A40-59768/12; ruling of the Arbitration court of
Moscow of 23.10.2013 on case № A40-59768/12 [online], www.kad.arbitr.ru (accessed 12.11.2017).

Ruling of the Supreme Court of the Russian Federation of 11.04.2016 № 305-ЭС16-581 (4) on case № A40109679/2013; ruling of the Arbitration Court of Moscow circuit of 14.12.2015 № Ф05-3638/2014 on case № A40109679/2013; ruling of the Ninth Arbitration Court of Appeal of 11.08.2015 on case № A40-109679/2013 [online], www.kad.arbitr.ru (accessed 14.10.2017).

Ruling of the Supreme Court of the Russian Federation of 24.06.2016 № 309-ЭС14-8665 (8) on case № A7626516/2013; ruling of the Arbitration Court of the Ural District of 01.03.2016 № Ф09-6924/14 on case № A7626516/2013; ruling of the Eighteenth Arbitration Court of Appeal of 17.11.2015 on case № A76-26516/2013; ruling of the Arbitration Court of Chelyabinsk region of 18.09.2015 по делу № A76-26516/2013 [online], www.kad.arbitr.ru (accessed 8.09.2017).

Ruling of the Supreme Court of the Russian Federation of 25.08.2016 № 305-ЭС15-16930 (3) on case № A4054279/2014; ruling of the Arbitration Court of Moscow circuit of 11.03.2016 № Ф05-9105/2015 on case № A4054279/2014; ruling of the Ninth Arbitration Court of Appeal of 16.11.2015 on case № A40-54279/2014 [online], www.kad.arbitr.ru (accessed 15.12.2017).

Rulings of the Supreme Court of the Russian Federation of: 25.08.2016 № 305-ЭС15-16930 (3) case № A4054279/2014; of 29.07.2016 № 305-ЭС14-13533 case № A40-77625/2012; rulings of the Arbitration court of Moscow Circuit: of 04.04.2016 № Ф05-16138/2012 case № A40-77625/2012; of 11.03.2016 № Ф05-9105/2015 case № A40-54279/2014 [online], www.kad.arbitr.ru (accessed 5.10.2017).

\section{Authors biographies:}

Elena Chernikova - Doctor of juridical sciences, candidate of economic sciences, head of the Department of Legal Regulation of Economy and Finances at the Institute of Public Administration and Management of the Russian Presidential Academy of National Economy and Public Administration, Moscow, Russia.

Valery Bykov - Candidate in Economics, Assoc. Prof. of Department of Legal Regulation of Economics and Finance in International Institute of Public Administration and Management of Russian Presidential Academy of National Economy and Public Administration, Judge of the Tenth Arbitration Appellate Court, Moscow, Russia. 